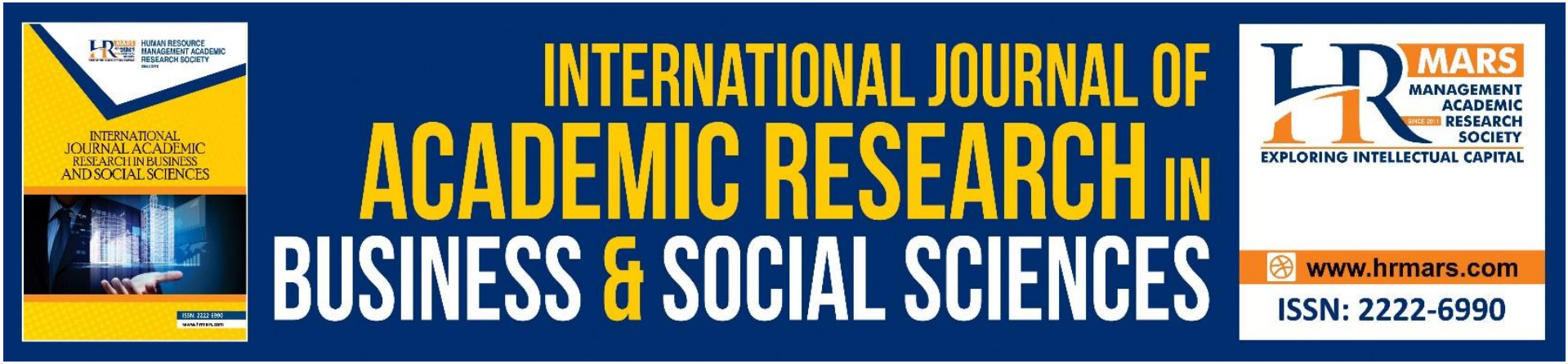

\title{
CDIO-TRIZ-Based Approach on Manufacturing Quality Improvement
}

Norashady Mohd Noor, Norazam Aliman, Wan Mohd Naguib Wan Abd. Rahman, Alawiah Abdullah, Muhammad Ammar lqwan Ruslan

To Link this Article: http://dx.doi.org/10.6007/IJARBSS/v11-i1/9037

DOI:10.6007/IJARBSS/v11-i1/9037

Received: 07 December 2020, Revised: 10 January 2021, Accepted: 18 January 2021

Published Online: 31 January 2021

In-Text Citation: (Noor et al., 2021)

To Cite this Article: Noor, N. M., Aliman, N., Rahman, W. M. N. W. A., Abdullah, A., \& Ruslan, M. A. I. (2021). CDIO-TRIZ-Based Approach on Manufacturing Quality Improvement. International Journal of Academic Research in Business and Social Sciences, 11(1), 1005-1014.

Copyright: @ 2021 The Author(s)

Published by Human Resource Management Academic Research Society (www.hrmars.com)

This article is published under the Creative Commons Attribution (CC BY 4.0) license. Anyone may reproduce, distribute, translate and create derivative works of this article (for both commercial and non-commercial purposes), subject to full attribution to the original publication and authors. The full terms of this license may be seen at: http://creativecommons.org/licences/by/4.0/legalcode

Vol. 11, No. 1, 2021, Pg. 1005 - 1014

Full Terms \& Conditions of access and use can be found at http://hrmars.com/index.php/pages/detail/publication-ethics 


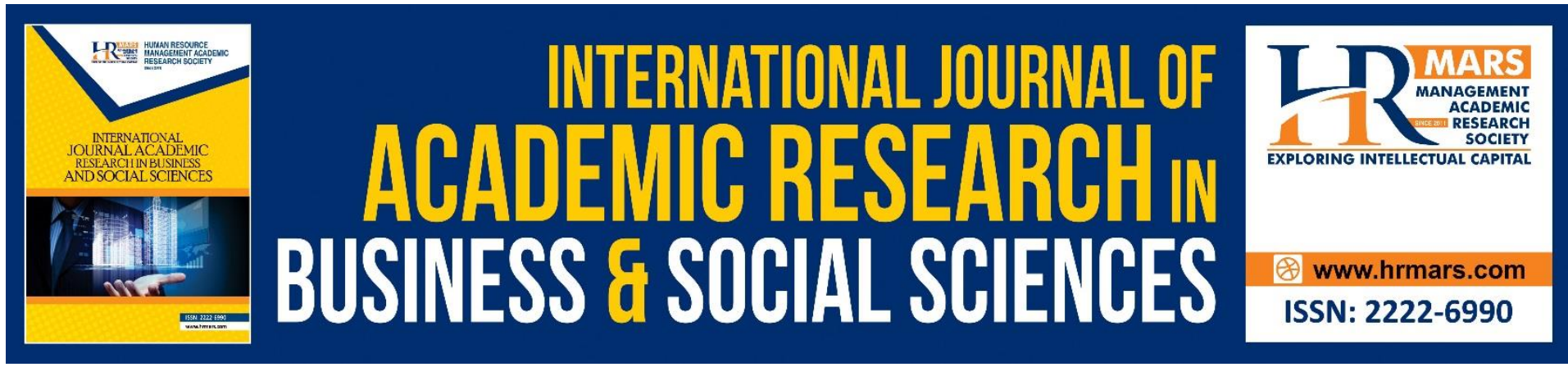

\title{
CDIO-TRIZ-Based Approach on Manufacturing Quality Improvement
}

\author{
Norashady Mohd Noor, Norazam Aliman, Wan Mohd Naguib \\ Wan Abd. Rahman, Alawiah Abdullah, Muhammad Ammar \\ lqwan Ruslan
}

Polytechnic Centre of Technology Automotive and Manufacturing, Politeknik Sultan Azlan Shah, Behrang Stesyen, 35950 Behrang, Perak, Malaysia.

\begin{abstract}
Creativity is important in the quality improvement in production assembly line. The methodology of problem solving usually included in different knowledge domains. Traditionally, the solution ideas come intuitively or logically, depending on creativity and experience of process engineers. The tools such as Conceiving, Designing, Implementing, Operating (CDIO) and TRIZ (Russian acronym for the "Theory of Inventive Problem Solving) can be used to generate the idea of quality improvement. Therefore, the paper aims to present a strategy called CDIO-TRIZ which to be used as a tool for improvement on quality defect in production assembly line. Through CDIO-TRIZ approach, an application to improve product quality in production line was used to demonstrate the capability of the proposed methodology. As a result has indicated, CDIO-TRIZ approach is proven can be used to generate solution for quality improvement in manufacturing system.
\end{abstract}

Keywords: CDIO, TRIZ, Quality Improvement Tool, Line Production

\section{Introduction}

Production lines comprise a set of sequential process whereby raw materials are out through a refining operation to produce a product that is reasonable for consumer market or industrial market; or components that are assembled to make a semi finish or finished product. In the production line, each product being produced will go through quality inspection such as defect inspecting, labelling and packing before the product is released (Swee et al., 2017). The product with a quality problem will undergo a refining or re-working process. High rates of product rejection will be resulted in wasted time and escalating raw material costs. Therefore, identifying the root cause of problem and solution is vital in production line. However, innovative strategy to overcome those factors required in term creativity and design thinking strategy to solve the problem (Shah et al., 2000).

The CDIO is a strategy for engineering fundamentals within the context of conceiving, designing, implementing, operating (Liu et al., 2005). It is universal approach in thinking strategy focuses on three mutually supporting elements (Brown, 2009), that is user desire, technical possible with current technology, and have a great opportunity in market. Through 
the CDIO, it can guide the engineer to design a problem solution to become more holistic as it requires a good understanding of user needs through empathy studies, and various ideation and iteration stages (Monsalve et al., 2016). However, these methods still have their limitations, where the requirements that need to be achieved in the designing stage are not always clear.

TRIZ is theory of inventive problem solving or in Russian known as "Teoriya Reheniya Izobreatatelskikh Zadatch", was founded in 1940's by Genrich Altshuller (Altshuller, 2002). He had study 200,000 patents of intellectual property and discover 40,000 patents according to innovative patterns of design. Finding from his study revealed that the solution of problem were repeated thus subsequently generated 40 inventive principles tools (Ekmekci \& Koksal, 2015). TRIZ is effective, since it is not just a methods, but overcoming development contradictions, which results in inventive solutions generation (Münzberg et al., 2016).

Based on advantages of both CDIO and TRIZ, this paper proposes a strategy for improving product quality in the production line by adopting TRIZ in CDIO, which known as CDIO-TRIZ. The following are details on how CDIO-TRIZ is applied in this study.

\section{Problem Background}

A dashboard or instrument panel (IP) is a control panel which is located directly in front of the driver of the vehicle, displaying instrumentation and controls for the operation of the vehicle. In a modern vehicle, IP contained a wide range of gauges and controls, such as information, climate control, entertainment systems, fuel level, gearshift position indicator, seat belt alarm and many others. Currently, moulding process are widely applied in IP production including automobile industries. Burr is main issues which effected to the quality of production and will eventually cause the part to be rejected.

\section{Problem Statement}

Observations indicate that there are several possible causes of product rejection that are produced through molding process. The problem daily report has been used to collect information about the defect types generated in daily production. Based on the report, the defects can be divided into five categories; there are over trim, short mould, black dot, silver streak and flow mark. Table 1 shown the data collected for 3 months starting on October 2018 to December 2018.

Table 1. The quantity rejection on October - December 2018

\begin{tabular}{|c|c|c|c|c|c|}
\hline \multirow{2}{*}{ Type of reject } & \multicolumn{5}{|c|}{ Month } \\
\cline { 2 - 6 } & October & November & December & $\begin{array}{c}\text { Total } \\
\text { (Quantity) }\end{array}$ & Total (\%) \\
\hline Over trim & 480 & 520 & 440 & 1440 & 9.23 \\
\hline Short mould & 80 & 100 & 40 & 220 & 1.41 \\
\hline Black dot & 130 & 100 & 100 & 330 & 2.12 \\
\hline Silver streak & 70 & 120 & 80 & 270 & 1.73 \\
\hline Flow mark & 40 & 80 & 80 & 200 & 1.28 \\
\hline Total reject & 800 & 920 & 740 & 2460 & 15.77 \\
\hline Total demand & 5200 & 5200 & 5200 & 15600 & \\
\hline
\end{tabular}


The comparison of defect types for 3 months is shown in Figure 2. The over trim shows that it dominates the highest number of defects compare to others; this indicates that a comprehensive strategy must be emphasized to reduce the rejection product.

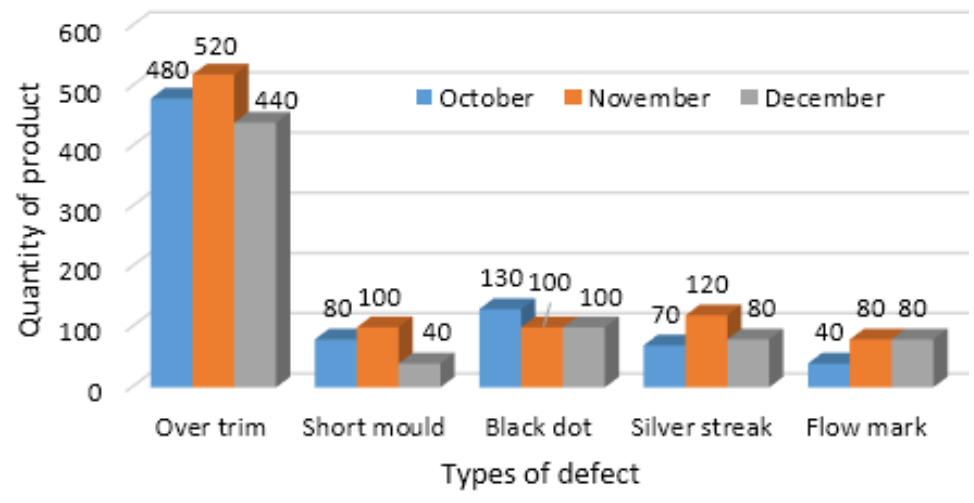

Figure 2: Comparison of defect types within October 2018 to Dec 2018

This paper will discuss the solving strategy using CDIO-TRIZ and how the technique can be used to solve the problem. The tool namely burrs jig-fixture removal (RJFR) has been proposed to solve the over trim issue. The CDIO-TRIZ method is used in this study; the effectiveness of the RJFR is evaluated and analyses at the end of this paper.

\section{Methodology}

In this paper, the IP quality issues occurred at one of manufacturing factory in Malaysia is being investigated and solved. The CDIO approach is used which consist of four stages i.e. Conceive, Design, Implement and Operate. During the design stage, the TRIZ philosophy is used to generate the idea for propose problem solving. The framework of methodology is shown in Fig. 1.

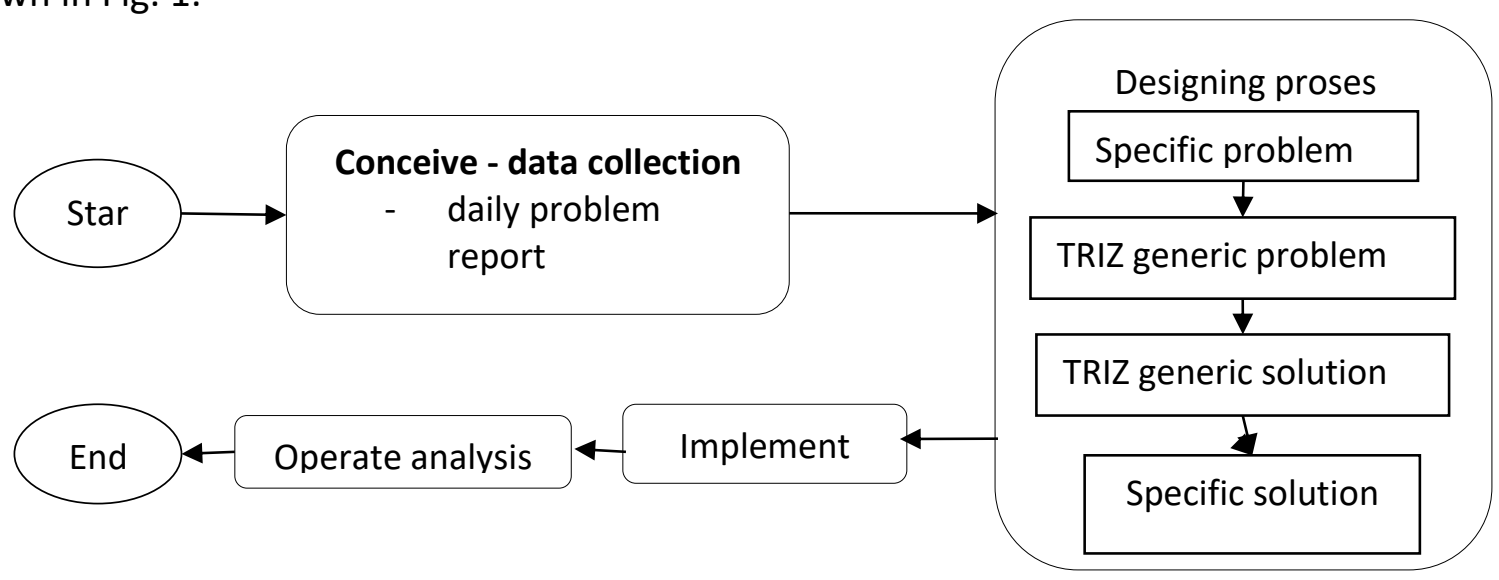

Figure 1. Flow Chart Methodology

First stage is Conceive, descriptively as defines the problem issue, identify the suitable techniques to collect the information and identify the cause of quality issues. For the data information, the input of quality issues is collected from the Quality Control Department. 
From tabulated data in Figure 2, majority of quality issue came from Over Trim defect and the cause of Over Trim needs to be explored. A case study is conducted to identify the root cause of the problem. Descriptively, Burr or uneven edges is unwanted by-product generated during production process. Burr is unwanted uneven edges to production part due to unsatisfactory appearance in finished production parts. Currently in order to remove burr or uneven edges to these finished production products, two production operators will manually remove the burr defect. Figure 4 shows the process of burr removal manually. The burr removal using manual process can be described as using cutting pliers and a knife as cutting tool to remove the burr. The manual process is repeated several thousand times a day by two operators. This rework burr removal process has resulted is high defect rates due to inconsistency or burr removal method. The finished production parts were damaged and need to be scrapped. The reason is the manual burr removal process is very long, ergonomically hazardous process, structure of the finished body parts become risk of defect/damaged, thus contributed to the high rejection part.

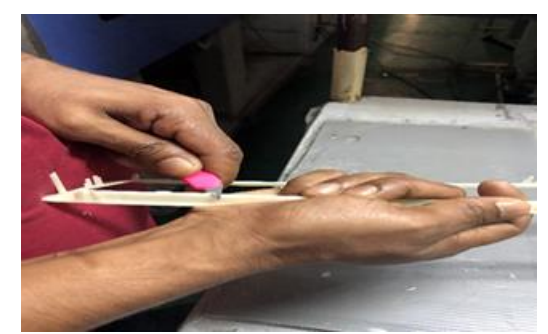

Figure 4: Manual Process of Burr Removal

Second is Designing stage which the mechanism to solve issues of over trim due to human factors is designed. The solution can be achieved via TRIZ philosophy in four steps: firstly, analyse the attribute of problems and determine the parameter "feature to improve" and "feature to worsening"; secondly, identify both parameters among the 39 engineering parameters of TRIZ; thirdly, generate solution using contradiction matrix and; fourthly, generate specific solution based on TRIZ generic solution. 
Table 2. Contradiction Matrix

\begin{tabular}{|r|l|l|l|l|}
\hline $\begin{array}{r}\text { Feature } \\
\text { to } \\
\text { improve }\end{array}$ & $\begin{array}{l}\text { Feature to } \\
\text { worsening }\end{array}$ & TRIZ principle & $\begin{array}{l}\text { TRIZ } \\
\text { solution }\end{array}$ & Specific solution \\
\hline 9 - speed & $\begin{array}{l}\text { 29- } \\
\text { panufacturing } \\
\text { precision }\end{array}$ & $\begin{array}{l}\text { 10-Preliminary action } \\
\text { 28-Mechanics } \\
\text { substitution } \\
\text { 32-Color changes } \\
\text { 25-Self-service }\end{array}$ & 28 & $\begin{array}{l}\text { Change from static (IP) to } \\
\text { movable fields as shown } \\
\text { in Figure 4. Previous } \\
\text { solution, the tool is } \\
\text { moved on the IP surface. }\end{array}$ \\
\cline { 2 - 5 } & $\begin{array}{l}\text { 31- object- } \\
\text { generate } \\
\text { harmful }\end{array}$ & $\begin{array}{l}\text { 2-Taking out } \\
\text { 24-Intermediary } \\
\text { 35-Parameter changes } \\
\text { 21-Skipping }\end{array}$ & 35 & $\begin{array}{l}\text { Remove the burr on IP } \\
\text { surface using knife tool. } \\
\text { The illustration of tool } \\
\text { design is shown in Figure } \\
\text { 4. }\end{array}$ \\
\hline $\begin{array}{l}\text { 23- loss of } \\
\text { substance }\end{array}$ & $\begin{array}{l}\text { 35-Parameter changes } \\
\text { 29-Pneumatics and } \\
\text { hydraulics } \\
\text { 3-Local quality } \\
\text { 5-Merging }\end{array}$ & 5 & $\begin{array}{l}\text { Assemble identical or } \\
\text { similar parts to perform } \\
\text { parallel operations. It can } \\
\text { be achieved by design jig } \\
\text { and fixture as shown in } \\
\text { Figure 4 }\end{array}$ \\
\hline
\end{tabular}

There are two criteria to be considered for intending to solve the over trimming issue in manual process. Firstly, is the speed, which the manual operation time should be accelerated. Therefore, the feature to improve with referring to 39 engineering parameters is 9- speed while the feature to worsening is 29 - Manufacturing precision and 31 - object-generate harmful. Secondly is the burr shape on the finished product needs to be completely removed. Therefore, the feature to improve with referring to 39 engineering parameters is 12- shape, while the feature to worsening is 23 - loss of substance. The generated solution based on contradiction matrix and the specific solution is shown in Table 2. The design of RJFR is made using Computer-Aided Three-Dimensional Interactive Application (CATIA) software.

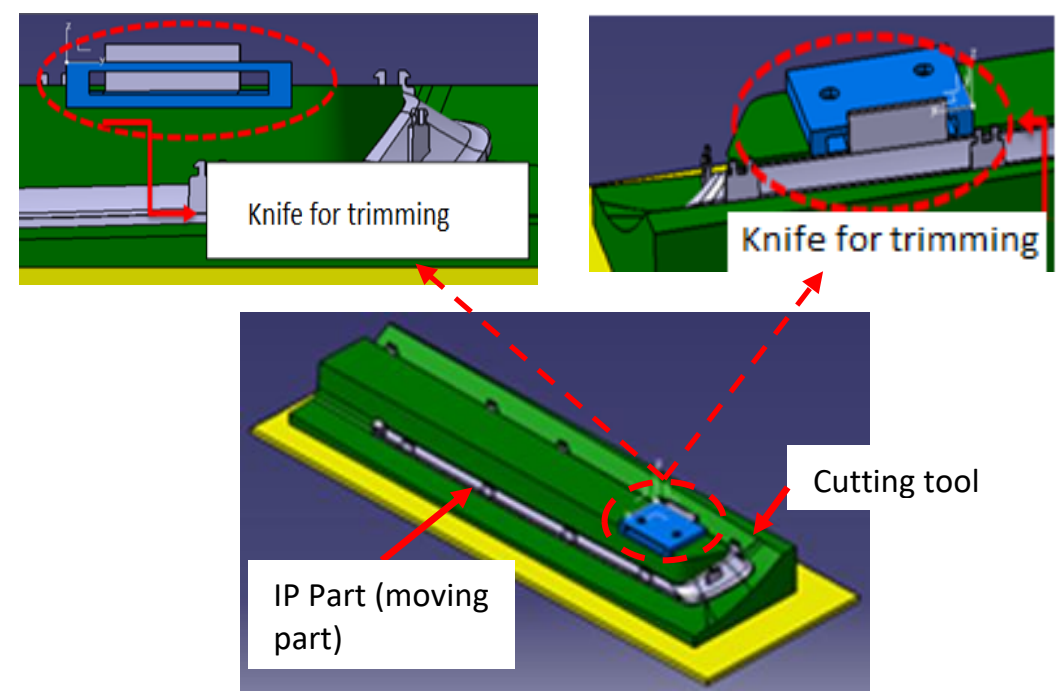

Figure 5: RJFR for trimming guidance. 
Third is implement stage, which it refers to the transformation of the RJFR design into manufacturing process. Figure 6 (a) show the process of RJFR fabrication using 3-dimension printer. The complete part of RJFR is shown in Figure 6(b).

The last stage is operate means the evaluation of the effectiveness of propose RJFR in burr removal process. The evaluation of RJFR is conducted by comparing rejection quantity, material and process time in 1 cycle between manual burr removal process and using propose RJFR tool.

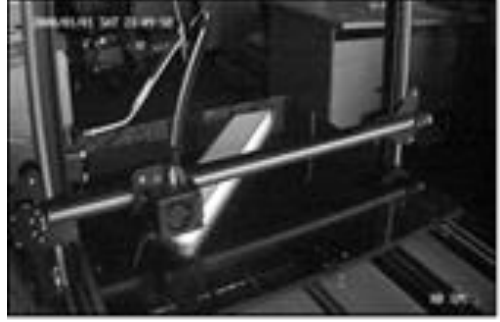

(a)

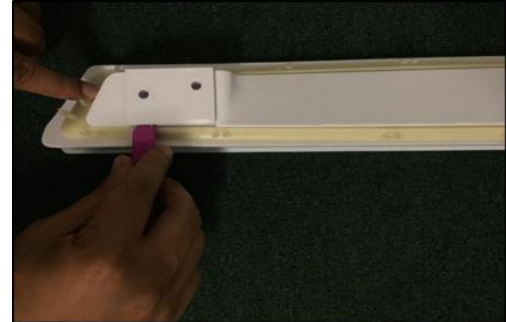

(b)

Figure 6: a) Fabrication process of RJFR using 3D printer b) Actual RJFR

\section{Result and Discussion}

The quantity of IP rejection rate according the types of defects, in manual operation and using RJFR is shown in Table 3. The quantity of over trim is showing initially $9.23 \%$ per total production in manual operation for October-December 2019 had decreased to $0.333 \%$ per total production in January-March 2019 when using RJFR. By comparing Over Trim defective parts for two production periods, tremendous decreased in defective parts up to 27 times.

Table 3. Rejection Quantity

\begin{tabular}{|l|c|c|}
\hline Defects & $\begin{array}{l}\text { Using manual operation } \\
\text { October to December 2018 } \\
\text { (pcs) }\end{array}$ & $\begin{array}{l}\text { Using RJFR } \\
\text { January to March 2019 } \\
\text { (pcs) }\end{array}$ \\
\hline Over trim & 1440 & 52 \\
\hline Short mould & 220 & 240 \\
\hline Black dot & 330 & 321 \\
\hline Silver streak & 270 & 220 \\
\hline Flow mark & 200 & 213 \\
\hline Total Defects & 2460 & 994 \\
\hline Total Production & $\mathbf{1 5 6 0 0}$ & $\mathbf{1 5 6 0 0}$ \\
\hline
\end{tabular}

The data in Table 4 indicates that the use of RJFR had a significant impact on the waste of raw materials in the IP manufacturing process. As much as $97.92 \%$ of the raw material can be saved due to defect by over trimming process in term of production quantities and tonnage of raw materials. 
Table 4. Rejection Material

\begin{tabular}{|l|c|c|c|c|c|c|c|}
\hline \multicolumn{4}{|c|}{ Before RJFR } & \multicolumn{4}{c|}{ RJFR Period } \\
\hline $\begin{array}{l}\text { Month } \\
(2018)\end{array}$ & $\begin{array}{c}\text { Normal } \\
(\mathrm{pcs})\end{array}$ & $\begin{array}{c}\text { Rejection } \\
(\mathrm{pcs})\end{array}$ & $\begin{array}{c}\text { Rejection } \\
\text { material } \\
(\mathrm{kg})\end{array}$ & $\begin{array}{c}\text { Month } \\
(2019)\end{array}$ & $\begin{array}{c}\text { Normal } \\
(\mathrm{pcs})\end{array}$ & $\begin{array}{c}\text { Rejection } \\
(\mathrm{pcs})\end{array}$ & $\begin{array}{c}\text { Rejection } \\
\text { material } \\
(\mathrm{kg})\end{array}$ \\
\hline October & 5200 & $800 \mathrm{pcs}$ & 168.0 & January & 5200 & 30 & 6.30 \\
\hline November & 5200 & $920 \mathrm{pcs}$ & 193.2 & February & 5200 & 14 & 2.94 \\
\hline December & 5200 & $780 \mathrm{pcs}$ & 163.8 & March & 5200 & 8 & 1.68 \\
\hline $\begin{array}{l}\text { Total } \\
\text { Production }\end{array}$ & 15600 & 2500 & 525.0 & & 15600 & 52 & 10.92 \\
\hline
\end{tabular}

Table 5 shows the rejection quantity, its respective tonnage and related cost of material wastages for two production periods of manual method and using RJFR. The table has indicated tremendous reduction both in rejection quantity and rejection material tonnage respectively with cost saving of $97.2 \%$.

Table 5. Cost of Waste Material Rejection

\begin{tabular}{|c|c|c|c|c|c|}
\hline $\begin{array}{c}\text { Mode } \\
\text { operation }\end{array}$ & Month & $\begin{array}{c}\text { Rejection } \\
\text { quantity } \\
(\mathrm{pcs})\end{array}$ & $\begin{array}{c}\text { Weight of } \\
\text { material } \\
(\mathrm{kg})\end{array}$ & $\begin{array}{c}\text { Cost of waste } \\
\text { material rejection } \\
(\mathrm{RM})\end{array}$ & $\begin{array}{c}\text { Total } \\
\text { cost } \\
(\mathrm{RM})\end{array}$ \\
\hline \multirow{3}{*}{$\begin{array}{c}\text { Manual } \\
\text { operation }\end{array}$} & October 2018 & 800 & 168.0 & 3528.00 & \multirow{3}{*}{11025.00} \\
\cline { 2 - 5 } & November 2018 & 920 & 193.2 & 4057.20 & \\
\cline { 2 - 5 } & December2018 & 740 & 163.8 & 3439.80 & \multirow{2}{*}{229.02} \\
\hline \multirow{3}{*}{ RJFR } & Jan 2019 & 30 & 6.30 & 132.00 & \\
\cline { 2 - 5 } & Feb 2019 & 14 & 2.94 & 61.74 & \\
\cline { 2 - 5 } & March 2019 & 8 & 1.68 & 35.28 & \\
\hline
\end{tabular}

Table 6 shows cycle time of IP part, comparing by using manual operation and RJFR period. The result indicated time taken for trimming work using the RJFR was $11.32 \%$ faster than the manual process. 
Table 6. Work Sequence in ID Inspection, Finishing and Packaging

\begin{tabular}{|c|l|c|c|}
\hline Steps & Work sequences & $\begin{array}{l}\text { Manual } \\
\text { Process (s) }\end{array}$ & $\begin{array}{l}\text { Using RJFR } \\
\text { (s) }\end{array}$ \\
\hline 1. & IP Part remove out part from mold & 6 & 6 \\
\hline 2. & Hold part properly and put on the table & 5 & 5 \\
\hline 3. & $\begin{array}{l}\text { Inspect part from top view and upside down the } \\
\text { part }\end{array}$ & 10 & 10 \\
\hline 4. & If found any defects, put part into RED container & 4 & 4 \\
\hline 5. & Cut runner by using cutter & 8 & 8 \\
\hline 6. & Trim runner gate by using knife & $10^{*}$ & $4 *$ \\
\hline 7. & Put OK part inside plastic bag & 3 & 3 \\
\hline 8. & Put OK part into the standard packaging (polybox) & 3 & 3 \\
\hline 9. & Paste part label outside polybox at the right spot & 4 & 4 \\
\hline & Total & 53 & 47 \\
\hline
\end{tabular}

Note: * Work Sequence Step using RJFR

\section{Conclusion}

The ever improving quality on production line should be able to handle any quality issue in a speedy and cheaper cost. A new methodology, known as CDIO-TRIZ, has become an easy tool with innovative design ideas for process engineer applications. Through application of CDIOTRIZ, it was demonstrated the concept is capable to solve the burr defect to finished product. The CDIO-TRIZ tool helps process engineers strategize the cause of the problem and amicably generate more feasible idea which may lead to concrete solutions. Finally, the burr defect was successfully eliminated using by the innovative tool of the CDIO-TRIZ. It was proven that the use of the CDIO-TRIZ will assist process engineers to reduce cost of material, cycle time and manpower by refining or re-working existing process.

\section{Acknowledgement}

We would like to thank the people involved in making this article published and special appreciation to Polytechnic Centre of Technology, Politeknik Sultan Azlan Shah.

\section{Corresponding Author}

Norashady Mohd Noor

Department of Mechanical Engineering, Politeknik Sultan Azlan Shah, 35900, Tanjong

Malim, Perak, Malaysia

Email: norashady@psas.edu.my

\section{References}

Ekmekci, I., \& Koksal, M. (2015). Triz Methodology and an Application Example for Product Development Triz Methodology and an Application Example for Product Development. Procedia - Social and Behavioral Sciences, 195, 2689-2698.

Münzberg, C., Hammer, J., Brem, A., \& Lindemann, U. (2016) Crisis Situations in Engineering Product Development: A TRIZ Based Approach. Procedia CIRP (The International Academy For Production Engineering), 39, 144-149.

Swee, N. S. L., Toh, G. G., Yip, M. W., Keong, C. S., \& Tai, S. C. (2017). Applying Triz for Production Quality Improvement. MATEC Web of Conferences, 95, 10009. 
Brown, T. (2009). Change by Design: How Design Thinking Transforms Organizations and Inspires Innovation, New York, NY: Harper Business

Shah, J. J., Kulkarni, S. V., \& Vargas-Hernandez, N. (2000). Evaluation of Idea Generation Methods for Conceptual Design: Effectiveness Metrics and Design of Experiments, Journal of Mechanical Design, 122(4), 377-384

Altshuller, G. (2007). The Innovation Algorithm: TRIZ, Systematic Innovation and Technical Creativity. Worcester: Technical Innovation Center, Inc. 